\title{
Pengembangan Motif Batik Etno Majaphit Pada Komunitas Pembatik Desa Lakardowo Kecamatan Jetis Kabupaten Mojokerto
}

\author{
Masnia Ningsih, Rakhmad Saiful Ramadhani \\ Fakultas Ilmu Sosial dan Politik, Program Studi Ilmu Komunikasi \\ Universitas Islam Majapahit \\ Jl.Raya Jabon KM.07 Mojoanyar Mojokerto \\ Email: matsnaalmuna@gmail.com
}

\begin{abstract}
The association of ethno majapahit batik craftsmen who are members of the "Lakardowo Village Batik Craftsman" community is an association which is engaged in the production of handicrafts / crafts. Until now, at the age of about four years, the community has the ability to produce quality products that have regional characteristics. However, this community has several obstacles in being able to compete with fellow batik craftsmen from outside the Mojokerto area, among others; can not yet emerge a characteristic that has a strong character to elevate batik ethno majapahit Mojokerto, does not have a patent for the design of the motif or trademark patent, so that in competing with batik craftsmen from areas outside Mojokerto are still not confident and have not received full trust from the market. With the Participatory Rural Appraisal (PRA) method, through intensive workshops by exploring the existing potential, namely developing ethno majapahit batik motifs, as well as facilitating partners to have patent rights for the motives they produce and also trademark patents registered with Menkumham. And equip ethno majapahit batik craftsmen with online marketing skills that allow them to relate to a wider range of consumers.
\end{abstract}

keywords: batik ethno majapahit,local branding, participatory rural appraisal

\begin{abstract}
Abstrak
Perkumpulan para pengrajin batik etno majapahit yang tergabung dalam komunitas "Pembatik Desa Lakardowo" adalah sebuah sebuah Perkumpulan yang bergerak di bidang produksi kerajinan tangan/kriya. Sampai dengan saat ini, di usianya yang sekitar empat tahun, komunitas tersebut telah memiliki kemampuan untuk menghasilkan produk yang berkualitas dan memiliki ciri khas kedaerahan. Akan tetapi komunitas tersebut memiliki beberapa kendala untuk dapat bersaing dengan sesama pengrajin batik dari luar daerah Mojokerto, antara lain; belum bisa dimunculkan sebuah ciri khas yang berkarakter kuat untuk mengangkat batik etno majapahit mojokerto, belum memiliki paten untuk desain motif maupun paten merk dagang, sehingga dalam bersaing dengan pengrajin batik dari daerah diluar mojokerto masih belum percaya diri dan belum mendapatkan kepercayaan penuh dari pasar. Dengan metode Participatory Rural Appraisal (PRA), melalui kegiatan workshop intensif dengan menggali potensi yang ada yaitu mengembangkan motif batik etno majapahit, serta memfasiltasi mitra untuk memiliki hak paten atas motif yang dihasilkannya dan juga paten merk dagang yang terdaftar di Menkumham. Dan membekali para pengrajin batik etno majapahit dengan kemampuan marketing online yang memungkinkan mereka bisa berelasi dengan konsumen yang lebih luas lagi.
\end{abstract}

kata kunci: batik ethno majapahit,local branding, participatory rural appraisal

\section{PENDAHULUAN \\ Sejarah Batik Majapahit}

Sejarah batik diperkirakan dimulai dari masa Kerajaan Majapahit yang beribukota di Trowulan, Mojokerto. Di jaman Mapajahit atau lebih tepatnya pada abad XVII, awal permulaan pembatikan ditandai sebagai sebuah kegiatan keluarga keraton. Selanjutnya batik berkembang terus pada masa kerajaan Mataram, Surakarta sampai Yogyakarta. Oleh karena 


\section{Masnia dkk : Pengembangan Motif Batik Etno Majapahit Pada Komunitas Pembatik Desa Lakardowo Kecamatan Jetis Kabupaten Mojokerto}

itu, kesenian batik di Indonesia sesungguhnya telah dikenal sejak zaman Kerajaan Majapahit dan terus berkembang kepada kerajaan dan raja-raja berikutnya. Awalnya, batik yang merupakan seni gambar menggunakan malam dan pewarna di atas kain merupakan aktivitas seni kerajinan keluarga raja-raja zaman dulu, dan dikerjakan hanya terbatas dalam kraton saja dan hasilnya untuk pakaian raja, keluarga serta para "Abdi dalem". Namun karena banyak pengikut raja yang tinggal di luar kraton, maka kesenian batik pun ikut keluar kraton. Seiring perkembangan zaman, seni membatik akhirnya dapat ditiru oleh rakyat sekitar keraton dan selanjutnya meluas menjadi aktivitas kerja kaum wanita dalam mengisi waktu senggang. Kemudian, batik yang awalnya hanya pakaian keluarga kerajaan, kemudian menjadi pakaian rakyat yang digemari, baik wanita maupun pria.

Jawa Timur merupakan bagian cukup penting bag i munculnya sejarah batik di Indonesia. Karena sejarah telah mencatat di abad XVII pada era Majapahit-lah sejarah batik muncul. Batik yang telah menjadi kebudayaan di kerajaan Majahit, dapat ditelusuri di daerah Mojokerto dan Tulung Agung. Mojoketo adalah daerah yang erat hubungannya dengan kerajaan Majapahit semasa dahulu dan asal nama Mojokerto ada hubungannya dengan Majapahit. Kaitannya dengan perkembangan batik asal Majapahit berkembang di Tulungagung adalah riwayat perkembangan pembatikan didaerah ini, dapat digali dari peninggalan di zaman kerajaan Majapahit.

Daerah pembatikan di Mojokerto saat ini terdapat di Kwali, Mojosari, Betero dan Sidomulyo. Di luar daerah Kabupaten Mojokerto ialah di Jombang. Pada akhir abad ke-XIX ada beberapa orang kerajinan batik yang dikenal di Mojokerto (Batik MURI Jatim), bahanbahan yang digunakan saat itu kain putih yang ditenun sendiri dan obat-obat batik dari soga jambal, mengkudu, nila tom, tinggi dan sebagainya. Dalam rentang waktu cukup panjang, dunia batik di berbagai wilayah di Jatim khusunya Mojokerto memiliki perkembangannya sendiri. Hal itu ditandai dengan bermunculannya industri skala mikro kecil maupun skala rumah tangga yang terus menghasilkan produk dengan motif dan pewarnaan khas daerah masing-masing baik itu di wilayah kota maupun kabupaten Mojokerto . Ketekunan para pembatik itu menjadikan usaha batik tulis tetap eksis hingga tenaga-tenaga trampil yang menggunakan alat produksi berupa canting dan bahan baku malam berangsur mencapai usia lanjut.Tetapi generasi berikutnya juga telah lahir, dan mereka tidak rela jika potensi batik tulis di Mojokerto terancam punah. Itulah sebabnya, maka digali kembali jenis motif batik tulis khas daerah di Jatim bahkan dikembangkan pula motif baru, termasuk pengembangan aspek teknis pemrosesan serta upaya perluasan pasarnya.

\section{Batik Etno Majapahit}

Pengertian kata "etnografi" dalam Kamus Kajian Budaya (2014: 93) adalah pendekatan empiris sekaligus teoretis yang merupakan turunan dari antropologi, yang bertujuan utama untuk menghasilkan deskripsi yang mendetil dan holistik serta analisis budaya yang didasarkan pada kerja di lapangan yang intensif. Koentjaraningrat (1999: 1) mendefinisikan etnografi sebagai suatu deskripsi mengenai kebudayaan etnik dari suatu suku bangsa secara holistik (keseluruhan). Suhartatik dalam wawancaranya dengan Bambang Parikesit (wawancara: 29 Desember 2016) selaku guru mata pelajaran Seni Budaya di SMA Negeri 1 Gondang berpendapat bahwa etnografi berasal dari kata etno yang berarti ciri khas/etnik dan grafi yang berarti daerah tertentu. Batik Etno Majapahit dapat diartikan sebagai batik dengan ciri khas pada motifnya yang diambil dari suatu daerah yang ada di Mojokerto.

Istilah Batik Etno Majapahit adalah istilah yang dipakai atau diciptakan oleh bapak Hadi Sucipto yni, sekaligus seniman serta budayawan Mojokerto yang sangat peduli dengan 
perkembangan batik tulis Mojokerto. Menurut Hadi Sucipto penamaan batik tulis Etno Mojopahit merupakan batik motifnya tersimpan tuturan khas tentang kearifan lokal Majapahit. Dalam batik ini berusaha menggali potensi warisan Kerajaan Majapahit dengan mengambil ikon- ikon yang ada saat ini, bisa dari karya sastra, relief candi, arca, dimana dalam penciptaan motif - motif batik tersebut diambil berdasarkan budaya lokal dan simbolisasi dari nama daerah yang ada di Kabupaten Mojokerto yang merupakan wilayah kerajaan Majapahit, sehingga banyak ditemukan peninggalanpeninggalan sejarah di Kabupaten Mojokerto. Menurut Irawan dkk (2013: 3) dalam Penelitian Novia Suhartatik, mengatakan bahwa Majapahit memiliki peninggalan hasil budaya 15 berupa candi-candi. Kerajaan ini memiliki arsitek-arsitek yang sangat ahli menggunakan batu bata yang telah digunakan pada candi di masa sebelumnya. Candi-candi Majapahit berkualitas baik secara geometris dengan memanfaatkan getah pohon anggur dan gula merah sebagai perekat batu bata. Contoh candi Majapahit yang masih dapat ditemui sekarang adalah candi Tikus dan candi Bajang Ratu di Trowulan, Mojokerto. Kekayaan berbagai macam budaya, kesenian dan letak wilayah yang memiliki ciri khas tersendiri dari daerah lain yang ada di Kabupaten Mojokerto, dapat digunakan sebagai ide dalam pembuatan batik tulis etnik Mojokerto yang semata-mata untuk melukiskan sebuah wilayah di Kabupaten Mojokerto ke dalam suatu bentuk karya batik (Suhartatik,2017)

Penaman Batik Tulis Etno Mojopahit adalah sebuah strategi Local Branding yang bernas, karena dari penamaan ini akan memicu kreatifitas dalam melahirkan motif - motif baru batik Majapahit, serta akan memberikan sebuah komunikasi yang persuasif sekaligus efektif sebagai sebuah strategi komunikasi pemasaran batik tulis yang ada di Mojokerto. Batik Etno Majapahit akan menjadi sebuah brand yang modern sekalaigus dinamis, meski menggali dari kearifan lokal peninggalan Majapahit di masa lalu.

\section{Profil Komunitas Pembatik Desa Lakardowo}

Bermula dari program Corporate Social Responsibility yang dilakukan oleh PT Putra Restu Ibu Abadi (PT PRIA), yaitu Perusahaan pengolah dan pemanfaat limbah B3 dn Non B3. Yang berlokasi di Desa Lakardowo Kecamatan Jetis Kabupaten Mojokerto yang berupaya melakukan Pemberdayaan Masyarakat dengan memberikan ketrampilan kepada warga desa Lakardowo dengan melakukan program pelatihan Batik Tulis Khas Mojokerto. Mengapa Batik? Karena Batik adalah identitas bangsa, batik dalam prosesnya jauh lebih sedikit dalam memakai air dan batik dalam perawatan sehari-hari juga jauh lebih sedikit memakai air sehingga dapat dibuat salah satu misi PT PRIA untuk melestarikan lingkungan. Mereka dilatih keterampilan mulai dari proses ngeblat, mencanting, mewarnai, nglorot, sampai menjadi selembar kain batik tulis.

Setelah dilatih para peserta program kemudian membentuk komunitas yang diberi nama "Komunias Pembatik Lakardowo" dan mulai mengerjakan batik tulis dan mulai bisa menerima order dari pihak lain yang meminati batik tulis khas Mojokerto. Dalam berproduksi digunakan brand/merk Batik JAKA yang mengembangkan batik motif "Etnografi Majapahit", sebab Batik JAKA lahir di Mojokerto yang merupakan tanah pusat pemerintahan Kerajaan Majapahit. Adapun produk unggulan yang ditawarkan oleh "Batik JAKA" adalah; pertama, Batik Etnografi Majapahit. Adalah batik yang didalam motifnya tersimpan tuturan khas tentang kearifan lokal Majapahit. Dalam batik ini berusaha menggali potensi warisan Kerajaan Majapahit dengan mengambil ikon- ikon yang ada saat ini, bisa dari karya sastra, relief candi, arca, bangunan atau tempat yang menyimpan situs peninggalan kerajaan Majapahit. Kedua, 


\section{Masnia dkk : Pengembangan Motif Batik Etno Majapahit Pada Komunitas Pembatik Desa Lakardowo Kecamatan Jetis Kabupaten Mojokerto}

Batik Pewarna Alam. Batik JAKA mengembangkan Batik dengan Zat Pewarna Alam, Sesuai hasil riset, batik produksi berbahan alam hanya mengeluarkan beban pencemaran COD 1000ppm jika dibandingkan batik lain yang mengeluarkan beban pencemaran 17.000ppm, sehingga batik pewarna alam lebih ramah lingkungan dibanding batik tulis yang menggunakan pewarna sintetis.

\section{Analisa Situasi}

"Komunitas Pembatik Desa Lakardowo" merupakan sebuah Perkumpulan yang bergerak di bidang produksi kerajinan tangan/kriya yang tergabung dalam sebuah brand usaha bernama "Batik JAKA"diresmikan pada tahun 2017, yang sekretariatnya berada di Dusun Kedung Palang Desa Lakardowo Kecamatan Jetis Kabupaten Mojokerto. Perkumpulan/komunitas ini diketuai oleh ibu Mustaidah dan dibantu sebagai sekretaris adalah pak Soleh. Sebagai pendamping para pembatik adalah Bapak Bagong Priatma. Perkumpulan/komunitas ini sementara memiliki anggota yang terdaftar adalah 10 sampai 15 orang. Tujuan dari keberadaan Perkumpulan ini adalah untuk memberdayakan dan meningkatkan skill para pengrajin Batik di Mojokerto yang selanjutnya diharapkan dapat menunjang peningkatan taraf ekonomi tentunya dengan tetap ramah lingkungan karena salah satu produksi dari perkumpulan pengrajin batik ini adalah memproduksi batik tulis dengan pewarna alami yang tujuan akhirnya adalah penyelamatan lingkungan.

Meskipun usia perkumpulan ini masih terbilang muda, namun motif batik yang telah dihasilkan sudah cukup banyak varian motifnya. Akan tetapi komunitas tersebut memiliki beberapa kendala untuk dapat bersaing dengan pengrajin batik dari luar daerah Mojokerto, antara lain ; belum bisa dimunculkan sebuah ciri khas yang berkarakter kuat untuk mengangkat batik etno majapahit mojokerto, belum memiliki paten untuk Desain motif maupun paten merk dagang, sehingga dalam bersaing dengan pengrajin batik dari daerah diluar mojokerto masih belum percaya diri dan belum mendapatkan kepercayaan penuh dari pasar, dan terakhir belum optimalnya media pemasaran produk batik etno majapahit, yang mana selama ini masih cenderung dilakukan dengan cara konvensional yakni dengan tatap muka saja.

Adapun Kendala secara detail Pengembangan Usaha yang dialami oleh mitra perkumpulan pengrajin batik majapahit Mojokerto antara lain disebabkan, pertama; Karena pengembangan motif yang berciri khas sesuai dengan potensi lokal berciri Majapahit di Mojokerto belum optimal. Sehingga belum bisa dimunculkan sebuah ciri khas yang berkarakter kuat untuk mengangkat batik majapahit mojokerto. Kedua; karena belum memiliki paten (HAKI) untuk Desain motif maupun paten merk dagang, sehingga dalam bersaing dengan pengrajin batik dari daerah diluar mojokerto masih belum percaya diri dan belum mendapatkan kepercayaan penuh dari pasar. Dan yang ketiga; belum optimalnya media pemasaran produk batik majapahit, yang mana selama ini masih cenderung dilakukan dengan cara konvensional yakni dengan tatap muka saja. Oleh karena itu diperlukan sebuah inovasi baru dalam hal transaksi jual belinya, sehingga tidak harus tatap muka melainkan bisa dilakukan dengan cara e-commerce.

\section{METODE PELAKSANAAN}

Program dilaksanakan dengan metode/pendekatan "berbasis komunitas" (community based approach), dan dengan partisipasi aktif masyarakat dapat memanfaatkan Participatory Rural Appraisal (PRA). Strategi PRA adalah strategi perencanaan yang lebih berorientasi pada karakteristik "dari bawah ke atas" atau bottom-up strategy. Strategi ini sesuai dengan pendekatan yang lazim ditentukan, yakni "berbasis komunitas" (community based approach) 
yang menilai tinggi partisipasi masyarakat dalam proses-proses perumusan masalah dan penyusunan perencanaan, dengan orang luar sebagai fasilitator sehingga pandangan dari dalam masyarakat sendiri (emik) merupakan pendekatan utama.

Bentuk dari metode PRA dalam hal ini adalah sebuah proses yang simultan dan berorientasi pada keikutsertaan secara aktif dari para pengrajin batik majapahit, yang diawali dengan :

1.Sosialisasi program kepada seluruh anggota perkumpulan pengrajin batik majapahit

Sosialisasi dilakukan diawal tahun untuk kegiatan yang akan dilakukan di tahun pertama, tahun kedua, maupun tahun ketiga.

2.Kegiatan workshop (pelatihan)

pada tahun pertama, kegiatan pelatihan yang dilakukan adalah pengembangan desain motif serta makna/filosofi batik "Etno Majapahit". Sedangkan di tahun kedua, dilakukan pelatihan pembuatan desain pola baju pada kain batik etno majapahit. Dan ditahun terakhir pelatihan yang dilakukan adalah pelatihan marketing online.

3.Melakukan kegiatan produksi dari hasil pelatihan-pelatihan pengembangan produk yang dilakukan, baik di tahun pertama yaitu memproduksi kain batik dengan desain motif etno majapahit yang baru hasil dari pengembangan saat pelatihan. Begitu juga ditahun kedua, melakukan produksi baju siap pakai dari hasil pengembangan pelatihan mengenai desain pola baju batik dengan motif etno majapahit.

4.Membukukan desain motif batik etno majapahit dalam bentuk buku referensi dan juga paten produk, baik untuk desain hasil pengembangan motif di tahun pertama, juga hasil pengembangan desain pola baju batik dari motif etno-majapahit di tahun yang kedua

5.pendaftaran Haki desain motif batik etno majapahit dan juga desain pola baju dengan motif batik etno majapahit, serta pendaftaran merk dagang keduanya kepada Kemenkumham.

\section{Local Branding}

Menurut Kotler brand adalah sebuah nama, istilah, tanda, symbol, rancangan atau kombinasi semua unsur yang digunakan untuk mengenali produk atau jasa dari seseorang atau sebuah kelompok penjual dari pesaingnya. Brand berfungsi sebagai satu ikatan yang kuat secara emosional antara pelanggan dan konsumen, tataran bagi opsi-opsi strategis dan kekuatan yang mempengaruhi financial. Kekuatan brand atau brand telah mengikat loyalitas pelanggan sehingga menghantarkan keberhasilan bisnis, ketangguhan dan produk yang bersaing. Brand dengan segala kekuatannya memiliki makna yang berbeda-beda dengan tujuan yang berbeda pula. MarkPlus Institute of Marketing mengidentifikasi 6 (enam) tingkatan brand, yaitu:

a.Atribut yakni sebuag brand yang diharapkan mampu mengingatkan suatu atribut atau sifat tertentu.

b.Manfaat yakni sebuah brand yang lebih dari seperangkat atribut.pelanggan tidak membeli atribut melainkan membeli manfaat baik yang fungsional (tahan lama) maupun emosional. Sebuah brand yang bagus tidak hanya memiliki kekuatan menjelaskan produk kepada pelanggan tetapi juga dibangun dengan konsistensi keunggulan produk. Pelanggan membeli sebuah produk tidak hanya berharap dari brandnya saja melainkan juga fungsi dari produk tersebut omotif.

c.Nilai yakni suatu brand menciptakan nilai bagi produsen. Nilai yang melekat pada produk biasanya dimaknai dengan cara yang sederhana tetapi mewakili keseluruhan sebuah produk. Pelanggan yang memakai gadget terbaru hendak menunjukkan dirinya sebagai sosok yang 


\section{Masnia dkk : Pengembangan Motif Batik Etno Majapahit Pada Komunitas Pembatik Desa Lakardowo Kecamatan Jetis Kabupaten Mojokerto}

peduli teknologi, update dengan teknologi terbaru dan berusaha menaikkan prestisenya dengan produk yang dipakai.

d.Budaya, yakni suatu brand mewakili budaya tertentu. Misalkan Mercedes mewakili budaya Jerman yang efsisen dan berkualitas tinggi. Honda mewakili budaya Jepang yang sarat degan teknologi dan impian masa depan. Produk yang diproduksi dinegara dengan budaya tinggi dan tingkat kedisiplinan tinggi dan kualitas yang terjamin akan lebih meyakinkan daripada yang diproduksi di negara yang secara budaya, kualitas lebih rendah.

e.Kepribadian, yakni suatu brand juga mampu merancang kepribadian tertentu.

f.Pemakai, yakni suatu brand akan memberi kesan kepada pengguna brand tersebut. Kesan tersebut lahir dari pengalaman menggunakan produk. Kualitas produk yang tinggi akan memberikan kesan dan pengalaman yang positif bagi pemakai dan akan melahirkan loyalitas terhadap produk tersebut.

Berdasarkan teori diatas konsep local branding dapat diartikan sebagai sebuah kegiatan pemberian nama, istilah, tanda, simbol, rancangan atau kombinasi semua unsur yang digunakan untuk mengenali produk atau jasa yang berasal dari potensi produk lokal yang berbasis kearifan lokal yang telah tumbuh di masyarakat. Dalam hal ini adalah seni kriya batik tulis yang merupakan warisan leluhur dan menjadi kearifan lokal di masyarakat social (local wisdom) yang di teruskan secara turun temurun.

\section{HASIL DAN PEMBAHASAN}

Untuk meningkatkan daya saing dari para pengrajin Batik Etno Majapahit Mojokerto ke tingkat yang lebih tinggi, yakni dari level lokal daerah ke level nasional sampai dengan internasional dibutuhkan sebuah strategi yang dapat menumbuhkan kepercayaan dan loyalitas konsumen. Hal tersebut dilakukan melalui tema "Local Branding" dengan 3 tahap; Pertama, dengan menggali lebih banyak skill \& knowledge para pengrajin batik mengenai kearifanl lokal Majapahit di Mojokerto untuk dijadikan motif batik etno majapahit yang di dasarkan pada filosofis dan sejarah dari masyarakat majapahit di wilayah Mojokerto melalui kegiatan workshop Pengembangan Motif Etno Majapahit. Sehingga hasil akhir produksi adalah sebuah produk Batik yang semakin kuat ciri khas daerahnya.

Kedua, tetap mengusung tema "Local Branding" dalam bidang manajemen adalah dengan mendaftarkan setiap desain batik dari setiap anggota perkumpulan/komunitas pengrajin batik etno majapahit tersebut ke Kementrian Hukum dan HAM, yang meliputi : Paten Desain Produk (HAKI Desain motif batik) dan Paten merk dagang pada tahun pertama. Setelah itu, produk dikenalkan kepada masyarakat sebagai calon konsumen melalui pameran kain batik hasil desain para pengrajin batik Majapahit. Sedangkan ditahun kedua, mendaftarkan paten desain pola baju batik dengan motif batik etno majapahit, dan sekaligus paten merk dagangnya. Setelah itu juga dikenalkan kepada masyarakat melalui kegiatan pameran kain batik dan peragaan busana yang berbahan kain batik hasil desain pola baju dari pelatihannya. Dan ketiga, dalam bidang pemasaran dilakukan dengan memanfaatkan teknologi informasi dalam bentuk website dan media dimana konten atau isian postingan yang ditawarkan memiliki karakter khusus seperti memberikan deskripsi filosofis dan sejarahnya pada setiap desain Batik majapahit yang sudah memiliki Paten untuk menjangkau wilayah pemasaran yang lebih luas. Di tahun yang ketiga nanti akan diberikan pelatihan untuk "Marketing Online" bagi para pengrajin batik Etno Majapahit, sehingga menjadi mandiri setelah program pendampingan ini selesai.

Kegiatan workshop yang terlaksana memberikan banyak manfaat bagi para peserta. Karena selain mampu mengeksplore kemampuan para pengrajin batik, juga memberikan 
pemahaman lebih kepada mereka bahwa segala hasil cipta dan karya yang besar itu berawal dari pemikiran yang berdasar. Dalam hal ini adalah bahwa motif batik yang dibuat oleh para pengrajin batik, jika mampu menghadirkan nilai filosofis dan sejarah yang ada didalam setiap detail desainnya, maka karya tersebut akan menjadi sangat berharga. Untuk kegiatan workshop pengembangan motif etno-majapahit mojokerto telah menghasilkan beberapa motif khas yang berasal dari kearifan lokal yang dimiliki oleh desa atau wilayah-wilayah tertentu di kabupaten mojokerto. Beberapa desain motif yang dihasilkan diantaranya sebagai berikut :

Motif Sekar Mojo; motif ini diambil dari Buah Maja nama latinnya Aegle Marmelos yang menjadi inspirasi lahirnya kerajaan besar di nusantara yaitu Majapahit, konon saat Raden Wijaya menerima sebidang tanah di hutan Terik, seorang prajurit memakan buah maja yang terasa pahit. Dari situlah nama Majapahit mulai didengungkan. Makna dari motif Sekar Mojo melambangkan perjuangan dan kerja keras dalam mencapai cita cita untuk kebesaran dan kemakmuran.

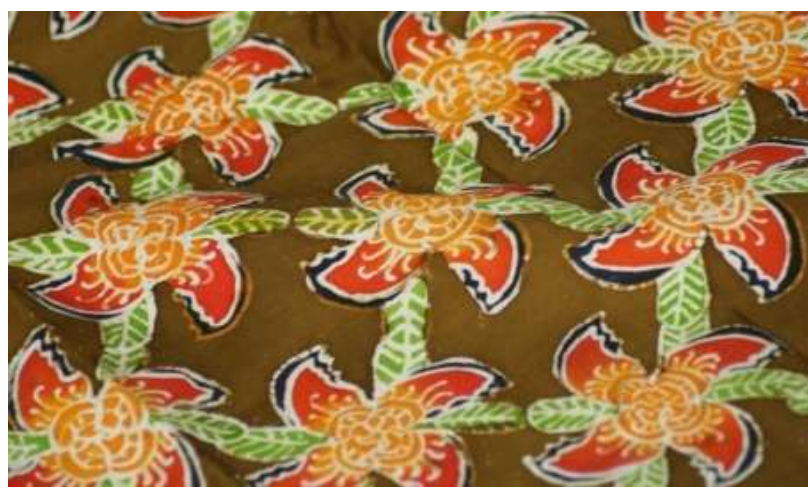

Gambar 1. Motif Sekar Mojo

Motif Sekar Sungsang; Sekar Sungsang adalah tumbuhan yang merupakan salah satu dari enam jenis dalam genus Gloriosa. Tumbuhan ini dijumpai di kepulauan Nusantara, merambat dengan umbi yang dapat bertahan pada keadaan kering. Makna dari motif Sekar Sungsang adalah ia dapat membalik anasir negatif yang ada pada kehidupan. Dalam motif Sekar Sungsang tersimpan doa yang membalik keadaan negatif, contohnya yang benci menjadi suka, yang berduka bisa menjadi bahagia.

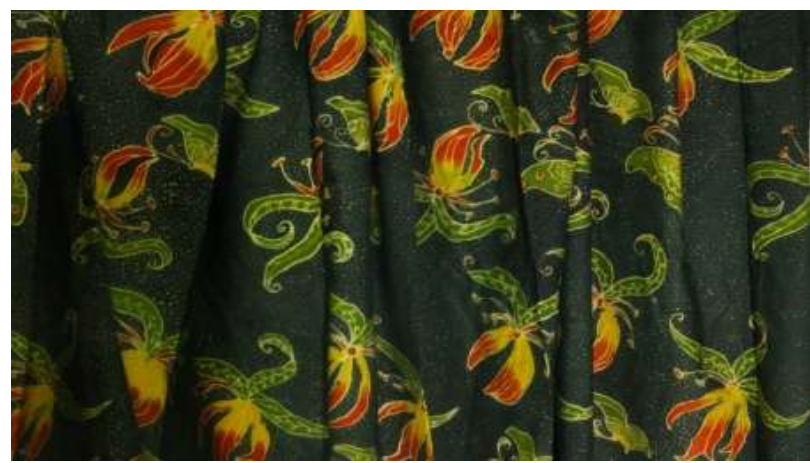

Gambar 2. Motif Sekar Sungsang

Motif Candi Cungkup; Mengambil ide dari relief Candi Cungkup yang terdapat di Desa Kesimantengah, Kecamatan Pacet, Mojokerto. Pada relief yang berada di dinding candi, menggambarkan kisah Ramayana, yaitu kisah penculikan Dewi Sintha istri Rama oleh 
Rahwana atau Dasamuka. Dimana Dewi Shinta mendapatkan pertolongan dari Hanoman. Secara garis besar kisah Ramayana menunjukkan bahwa manusia itu harus bergelut dengan dirinya sendiri terlebih dahulu sebelum mencapai pencerahan.

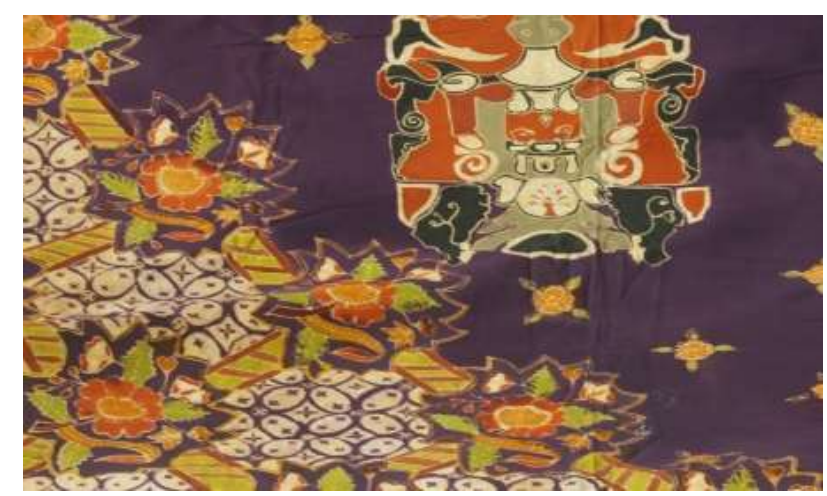

Gambar 3. Motif Candi Cungkup

Motif Jataka, Mengambil ide dari relief Candi Cungkup yang terdapat di Desa Kesimantengah, Pacet, Mojokerto. Pada relief yang berada di dinding candi, menggambarkan kisah Jataka, saat Budha berujud Kelinci. Didalam kisah tersbut sang kelinci melakukan pengorbanan masuk kedalam api pembakaran namun tidak terluka sedikitpun. Untuk mengenang pengorbanan suci kelinci itu keseluruh dunia, sang dewa menggambar bentuk kelinci di bulan. Motif Jataka edisi Sang kelinci menggambarkan pengorbanan mahluk, dimana Cinta dan Kasih Sayang menjadi pedoman hidup.

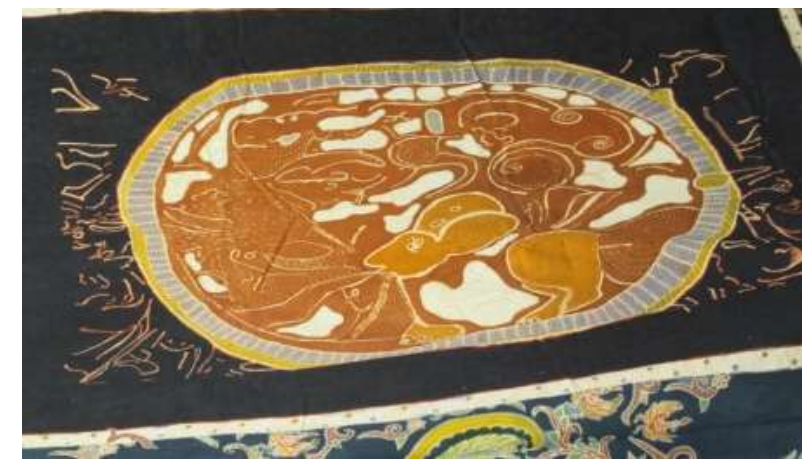

Gambar 4. Motif Jataka

Motif Merak Asmoro; Hadirnya motif Burung Merak dalam batik nusantara dipengaruhi oleh kebudayaan Cina yang mempercayai bahwa burung merak memiliki nilai filosofi yang sangat bagus dalam kehidupan. Berdasarkan A Dictionary of Chinese Symbols, burung merak merupakan lambang keagungan, keindahan, pelindung keturunannya dari segala bahaya, serta dapat mengusir pengaruh-pengaruh buruk dalam kehidupan.

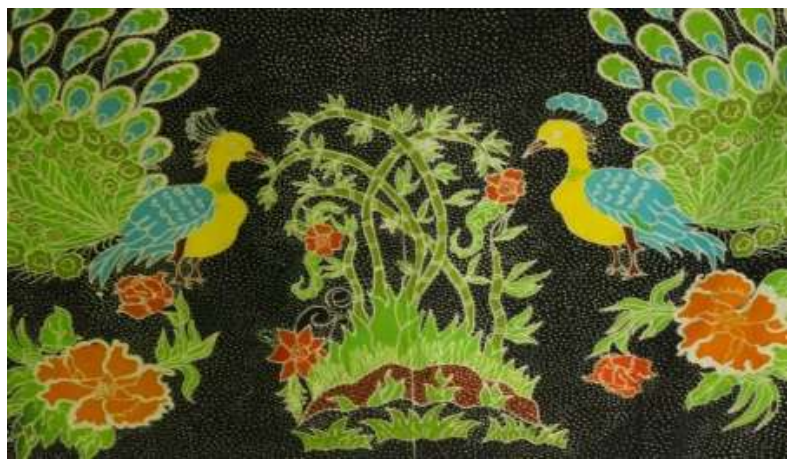




\section{Gambar 5. Motif Merak Asmoro}

Motif Sekar Mawar; Mawar atau awar-awar ben tawar. Buatlah hati menjadi tawar atau tulus, jadi niat tersebut harus berdasarkan ketulusan, menjalani segala sesuatu tanpa pamrih. Mawar merah melambangkan proses terjadinya atau lahirnya diri kita kedunia fana. Yakni lambang dumadine jalma manungsa melalui langkah Triwikrama. Motif Sekar Mawar melambangkan ketulusan seorang Ibu dalam melahirkan manusia di alam fana dimana jiwa raga kita diukir

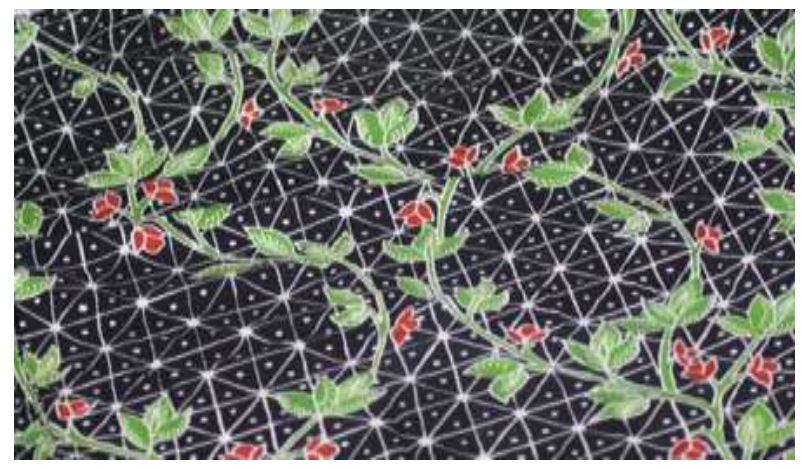

Gambar 6. Motif Sekar Mawar

\section{PENUTUP \\ Kesimpulan}

Kegiatan workshop yang terlaksana memberikan banyak manfaat bagi para peserta. Karena selain mampu mengeksplore kemampuan para pengrajin batik, juga memberikan pemahaman lebih kepada mereka bahwa segala hasil cipta dan karya yang besar itu berawal dari pemikiran yang berdasar. Dalam hal ini adalah bahwa motif batik yang dibuat oleh para pengrajin batik, jika mampu menghadirkan nilai filosofis dan sejarah yang ada didalam setiap detail desainnya, maka karya tersebut akan menjadi sangat berharga. Dengan diadakannya kegiatan ini, diharapkan mampu menjadi stimulan dalam rangka meningkatkan daya saing dari para pengrajin Batik Etno Majapahit Mojokerto ke tingkat yang lebih tinggi, yakni dari level daerah ke level nasional sampai dengan internasional.

\section{Saran}

Beberapa hal yang menjadi rekomendasi dari kegiatan workshop pengembangan motif batik etno-majapahit mojokerto, adalah :

a.Bahwa dibutuhkan pendampingan dan pembinaan secara berkala terhadap para pengrajin atau komunitas pembatik lokal mojokerto oleh pemerintah daerah kabupaten Mojokerto, sehingga mereka mampu bersaing dengan para pelaku industri kreatif yang sama dari daerah/kota lain.

b.Dalam hal pendistribusian tugas pendampingan dan pembinaan oleh pemerintah daerah dapat diturunkan kepada dinas perindustrian dan perdagangan (Disperindag) kabupaten Mojokerto. 


\section{DAFTAR PUSTAKA}

Ahmad, Hamzah. (1996). Kamus Pintar Bahasa Indonesia. Surabaya: "FAJAR MULYA".

Novia Suhartatik, (2017), Pembelajaran Batik Tulis Etnik Mojokerto Pada Mata Pelajaran Seni Budaya Di Sma Negeri 1 Gondang Mojokerto Jawa Timur (Skripsi), Program Studi Pendidikan Kriya Jurusan Pendidikan Seni Rupa Fakultas Bahasa Dan Seni UNIVERSITAS NEGERI YOGYAKARTA

Kotler Philip (2000), Marketing Management Millenium Edition, Prentice Hall International, Inc,

Kotler,Phillip \& Amstrong, Gary (1996), Principles of Marketing.Prentice Hall.Inc Markplus Institute of Marketing (2009), Brand Operation, Jakarta : Erlangga http://batik-tulis.com/blog/batik-yogyakarta diakses pada tanggal 20 juli 2019

http://www.wongmojokerto.com/2009/10/mojokerto-patenkan-6-motif-batik-tulis,diakses pada tanggal 26 mei 2019

Rekor MURI Batik Jawa Timur, 2011, Surabaya, Dinas Kominfo Provinsi Jawa Timur 